Slave Law and the Politics of Resistance

in the Early Atlantic World 



\title{
Slave Law and the \\ Politics of Resistance \\ in the Early Atlantic World
}

EDWARD B. RUGEMER

\author{
III \\ II \\ Harvard University Press \\ Cambridge, Massachusetts \\ London, England 2018
}


Copyright $(9) 2018$ by the President and Fellows of Harvard College All rights reserved

Printed in the United States of America

First printing

Library of Congress Cataloging-in-Publication Data

Names: Rugemer, Edward Bartlett, I97 I- author.

Title: Slave law and the politics of resistance in the early Atlantic world / Edward B. Rugemer.

Description: Cambridge, Massachusetts : Harvard University Press, 20 I8. I Includes bibliographical references and index.

Identifiers: LCCN 2018013048 I ISBN 9780674982994 (cloth)

Subjects: LCSH: Slavery_Law and legislation-Great Britain—Colonies. I Slavery-Law and legislation-United States. I Slave insurrections-Jamaica. I Slave insurrections-South Carolina. I Slavery-Barbados.

Classification: LCC K3267 .R84 2018 I DDC $342.08 / 7$ - dc2 3

$\mathrm{LC}$ record available at https://lccn.loc.gov/201801 3048

Jacket design: Jill Breitbarth

Jacket art: Engraving by Adolphe Duperly of the destruction of Roehampton Estate in the parish of St. James, Jamaica (I833) 
For Kate and our boys, Henry, Philip, and James 


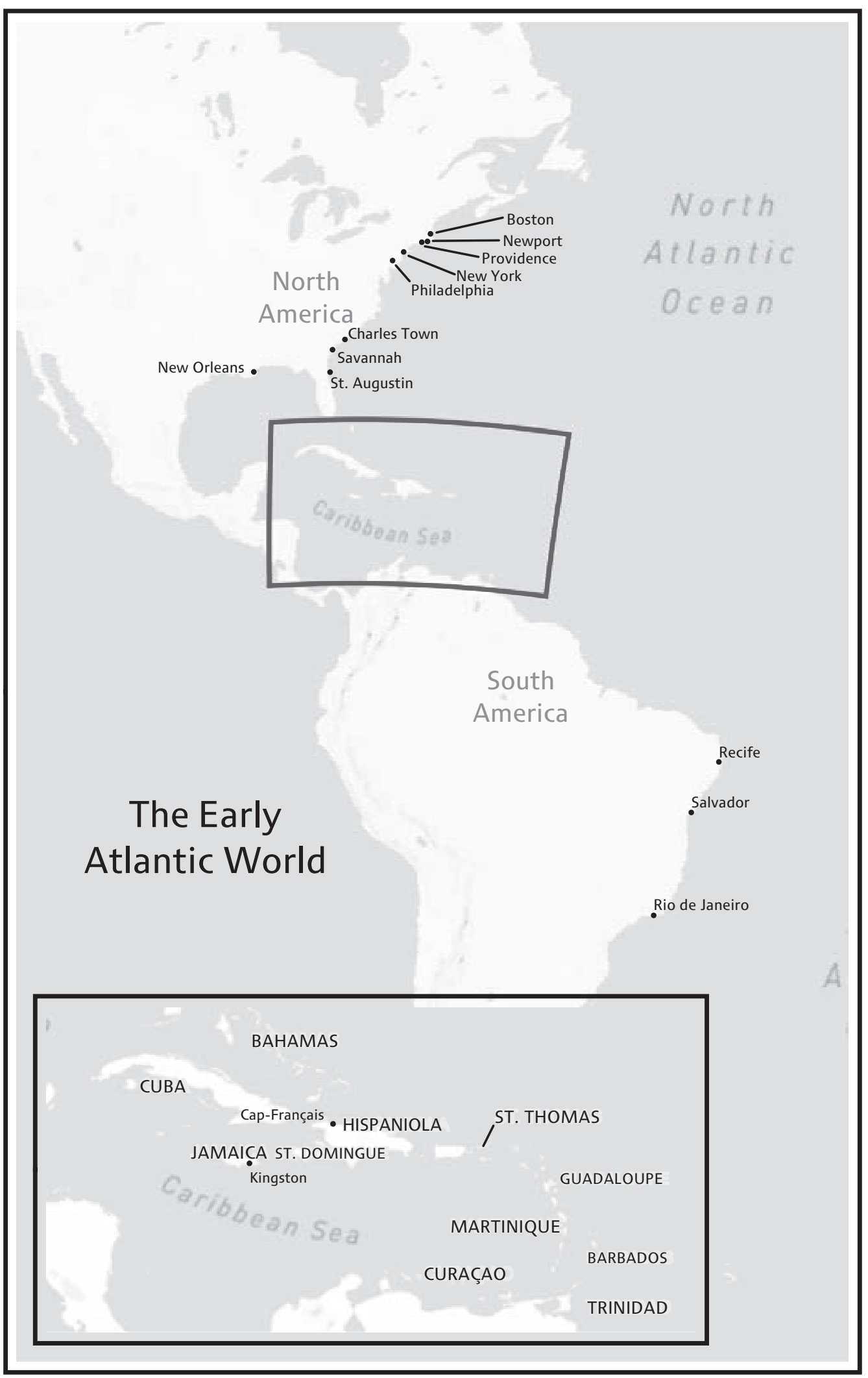




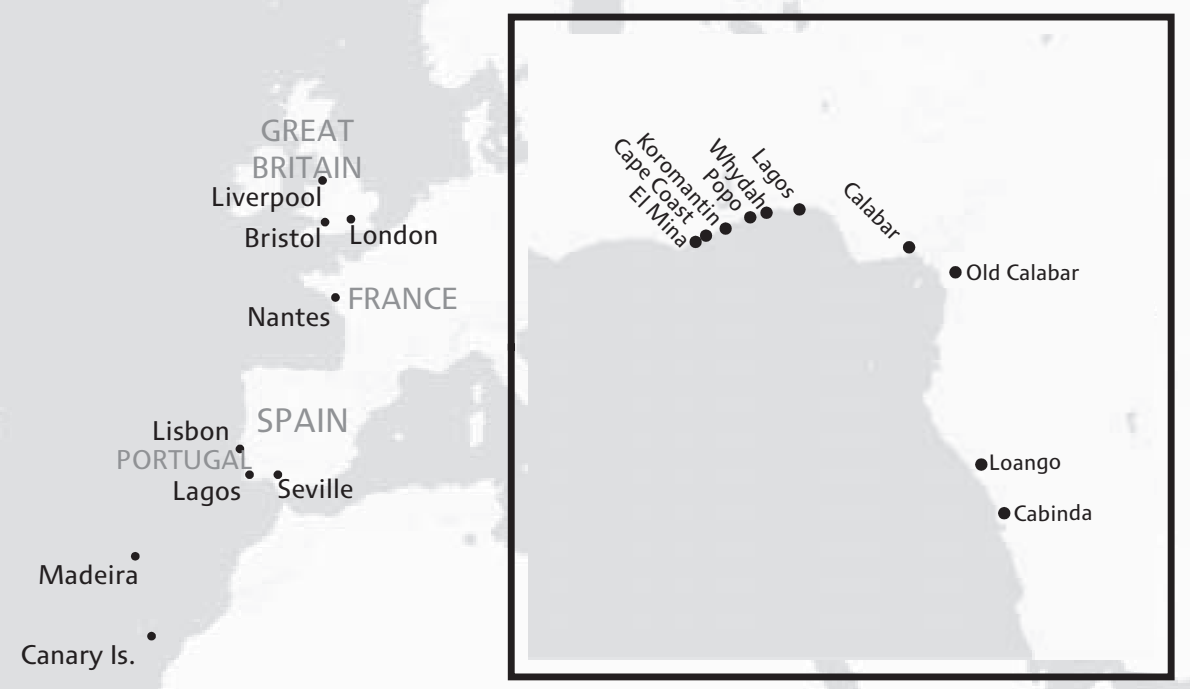

Senegambia

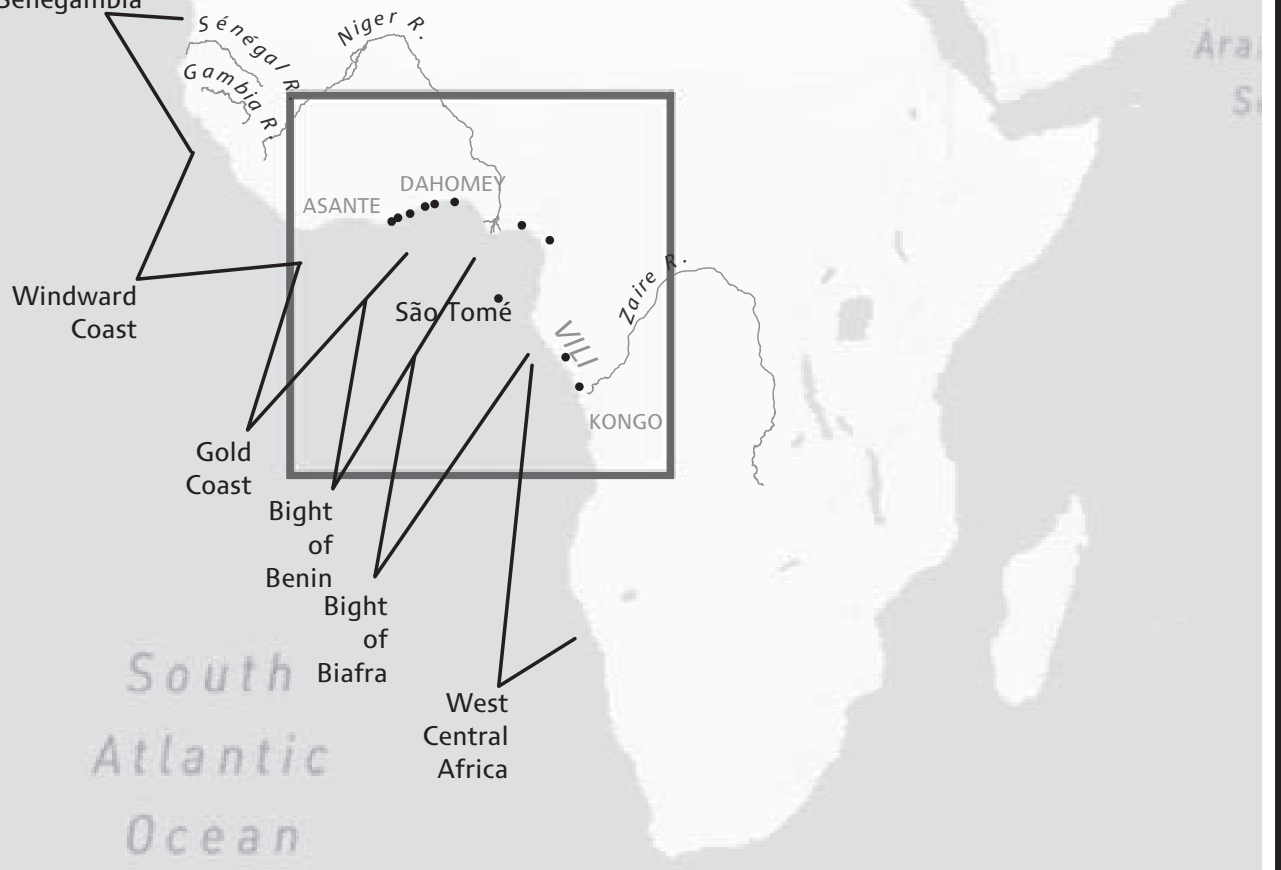

\section{The Early Atlantic World}

$0 \quad 500$ Miles 
